\title{
水理特性が付着藻類の一次生産特性 に与える影響に関する研究
}

\author{
戸田祐嗣 1 -赤松良久 ${ }^{2} \cdot$ 池田駿介 $^{3}$
'正会員 学士 (工) 東京工業大学助手 理工学研究科土木工学専攻 (テ 152-8552 東京都目黒区大岡山 2-12-1)
2 学生会員 修士 (工) 東京工業大学 理工学研究科土木工学専攻 (同上) \\ 3フェロー会員 工博 東京工業大学教授 理工学研究科土木工学専攻 (同上)
}

\begin{abstract}
水理特性の違いが河床付着藻類の一次生産特性に与える影響について, 現地観測および室内実験による定 量的調查を実施した. 現地観測では, 多摩川中の瀬と淵にモルタル製の模擬石を多数設置し, それらに付着 する藻類量を 1 週間間隔で55 日間計測した。 その結果, 瀬の河床䃋に付着する藻類は, 淵と比較して, 増 殖初期の生産活性が高いことが示された. 室内実験では, 日射量, 水質が全く同じ条件で流速などの水理特 性のみが異なる 4 つの開水路を作成し, 付着藻類現存量, 剥離量の測定および藻類の種分析を行った. 実験 の結果, 底面付近の乱れが大きな水路ほど, 藻類一次生産が大きくなることが明らかになった。
\end{abstract}

Key Words: periphyton, hydraulic characteristics, nutrients, primary production, detachment, nearbottom turbulence

1.序

䃯床河川中に見られる「瀬と淵」は河川魚類や昆 虫類の良好な生活の場を提供することが知られて おり ${ }^{1)}$, 河川生態環境を構成する主要な存在として 注目を集めている．瀬と淵の生物環境においては, 河床碩に付着する藻類が一次生産活動によって有 機物合成を担い，それらが魚類や昆虫類の餌とな ることによって食物連鎖を支えている，従って，付 着藻類の一次生産活動や現存量の特性を明らかに することは，瀬と淵の生態系をその根幹から解明 していくために重要な課題であると言える.

河床付着藻類に関する既往の研究は, 藻類種に 関する生物学的研究および藻類量やその一次生産 力に関する研究に大別される. 前者については陸 水生態学や藻類学の分野で数多くの研究が実施さ れており，例えば, Hoagland et al. $\left.{ }^{2}\right)$ は付着藻類が河 床に定着・繁茂する過程に関して, 初期段階では単 細胞型の珪藻綱の平面的な繁茂が生じ, その後, 口 ゼットを有する珪藻綱や系状体の緑藻綱・藍藻綱 が侵入し優占的に繁茂するようになることを報告 している。.また, Lobo et al. ${ }^{3}{ }^{3}$ は河床付着珪藻種と水
温，水深，BOD等の水質值に関する多変量解析を 行い, 珪藻類の種の多様性を表す指数（species richness）がある水質条件の下で最大の值を取るこ とを示している．以上のような藻類種に関する研 究成果から，ある環境条件下で出現する藻類種を 予測することが将来的に可能となることが期待さ れるものの，そこでは藻類量やその一次生産力に 関する検討は行われていない

一方, 付着藻類量やその一次生産力に関する研 究として以下の研究が挙げられる. Biggs et al. ${ }^{4)}$ は ニュージーランド中の 4 河川において付着藻類量 と藻類付着基盤上部における流速の計測を行い, ある流速值の下で付着藻類量が極大となることを 示している．池田ららは東京都秋川において瀬と淵 の付着藻類量（クロロフィル a 量）の計測を行い, 河床付近の日射量と藻類一次生産速度に関する文 献值 ${ }^{6)}$ を用いて夏期の日中の藻類一次生産力を算 出している。これらの調査から，河床付着藻類は湖 沼の水柱に匹敵するほどの高い一次生産力を有す ること, 一次生産活動は藻類付着基盤近傍の水理 特性の影響を受けることが明らかにされている。 しかし，上記の調査では日射量，栄養塩濃度あるい 


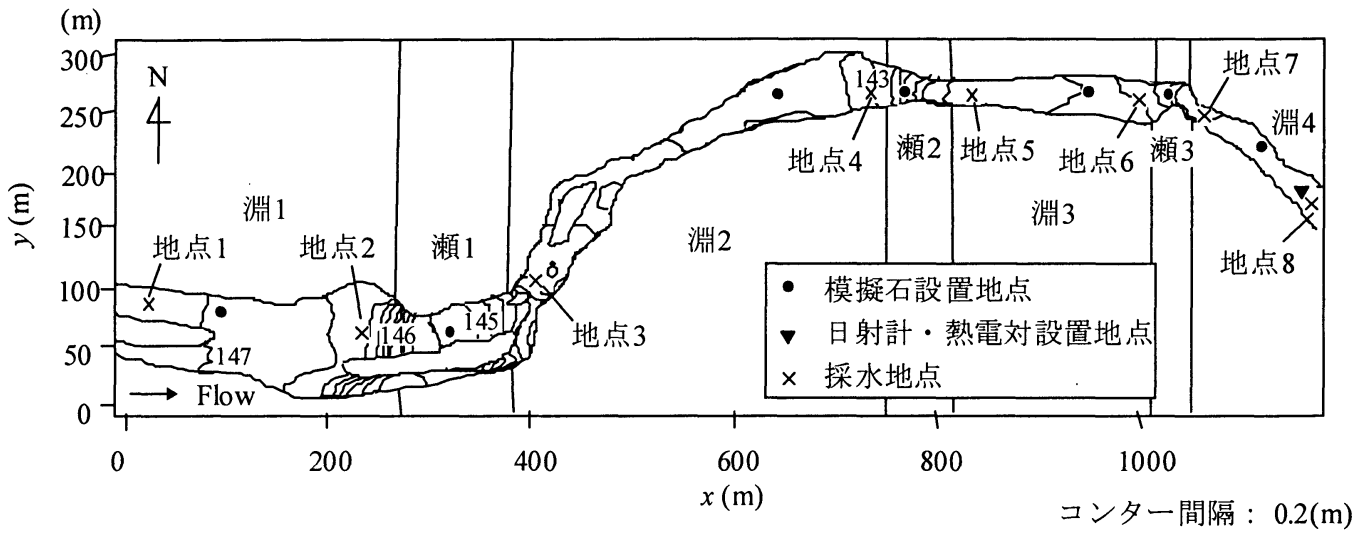

図-1 観測地地図と水位コンター（水位コンターの値は東京湾平均海水位を基準とした標高值 (単位: $\mathrm{m}$ ))

は藻類生育場の水理特性といった一次生産に影響 を及ぼす環境要素の計測が十分では無いため, 一 次生産と各種環境要素との因果関係を正確に把握 するには至っていない，また，筆者らは河床藻類の 一次生産特性について現地観測 7), 室内実験 ${ }^{81,9)}$ に より検討を行ってきが，そこでは藻類の種組成や 増殖過程の詳細に関する検討までは行われていな い. 藻類量, 日射量, 栄養塩濃度, 水理特性を同時 に捉えた質の高い実測データは非常に少なく（著 者の知る限りでは, Stevenson et al. ${ }^{100}$ による野外水 路を用いた藻類生育実験結果のみである), 近年盛 んに行われている数值解析による藻類一次生産に 関する研究 (例えば, DeAngelis et al. ${ }^{11)}$, Momo ${ }^{12)}$, Saravia et al. ${ }^{13)}$, 浅枝ら ${ }^{14)}$ ) も, 計算上の多数のパラ メータを仮定するか, 数少ない実験データから推 定しているため, 定量的評価を行える段階には 至っていない. 以上の様に, 河床付着藻類の一次生 産力に関する研究は, 藻類量や藻類種に加えて水 理量, 日射量, 栄養塩濃度を同時に捉えた定量的な 実測データが決定的に不足している状況にある.

以上のことから, 本報では, 河床付着藻類の一次 生産特性に関する, 藻類種, 藻類量, 日射量, 水質, 水理特性を総合的に捉えた定量的データベース構 築の第一歩として, 現地観測および室内実験によ り得られた付着藻類の増殖過程に関する実測デー 夕を報告する．また，これらのデータに基づいて， 藻類一次生産と水理特性との因果関係を定量的に 把握することを目的とする。

\section{2. 現地観測}

\section{（1）観測地及び観測方法}

\section{a) 観測地概要}

観測は多摩川中流域の下奥多摩橋（東京都青梅
市，多摩川河口より $59 \mathrm{~km}$ 地点）付近の瀬と淵にお いて実施した。観測地では, その約 $10 \mathrm{~km}$ 上流に位 置する発電施設によって流量の制御が行われてお り，観測期間中（1997年 7月 18 日〜同年 9 月 11 日） の河川流量はほぼ $10 \sim 14 \mathrm{~m}^{3} / \mathrm{s}$ の間に保たれていた. 観測対象領域内には支川の合流といったような大 きな横流入は無い. 図-1に観測地の地図と水位コ ンターを示す. 本観測では, 水位勾配が大きく, 水 面が空間的に波状に変動している領域を瀬とし， それ以外の領域を淵と分類した（以下，それぞれ上 流側から順に淵 1 , 瀬 $1, \ldots$ 瀬 3 , 淵 4 と称する). 淵 の中でも, 図 -1 中の $x$ 座標が $0 \mathrm{~m} \sim 250 \mathrm{~m}, 600 \mathrm{~m} \sim$ $700 \mathrm{~m}, 900 \mathrm{~m} \sim 1000 \mathrm{~m}$ の区間は一般に言われる深掘れ した淵ではなく, 川幅が広く, 水深の小さい淵（ト ロ）が形成されている.

\section{b) 観測方法}

1997 年 8 月 26,27 日に地形, 日射, 水質の測定を 行った. まず, 観測地の大局的な地形の特性を把握 するため, 河川形状, 河床高, 水面高の平板, 水準 測量を行った. 図-1 中の地点では, 8月 26 日 $6 \mathrm{am}$ $\sim 8$ 月 27 日 $6 \mathrm{am}$ にかけて, 鉛直上向き日射量, 下 向き日射量および水温を 10 分間隔で計測した。 日 射量の測定には日射計（MS-42, MS-62,（株）英弘 精機製)，水温の測定には熱伝対を用いている. 水 質に関して，8月 26 日 $6 \mathrm{am} \sim 8$ 月 27 日 $6 \mathrm{am}$ にかけて 図 -1 中の $\times$ の地点 (以下, 上流側から順に地点 1 , 地点 2 . . とする) で 2 時間間隔で溶存酸素濃度の測 定および採水を行った。溶存酸素濃度の計測には 簡易多項目水質計（U-10，（株）堀場製作所製）を 用いた. 採水されたサンプル水を持ち帰り，分光光 度計（DR-2000，（株）セントラル科学製）を用いた 比色法 ${ }^{15}$ )により栄養塩濃度（アンモニア態窒素 $\mathrm{NH}_{4}-\mathrm{N}$, 亜硝酸態窒素 $\mathrm{NO}_{2}-\mathrm{N}$, 硝酸態窒素 $\mathrm{NO}_{3}-\mathrm{N}$, 全 窒素 T-N, リン酸態リン $\mathrm{PO}_{4}-\mathrm{P}$, 全リン T-P) の測定 


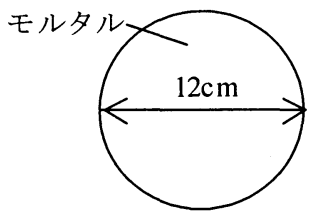

(a) 平面図

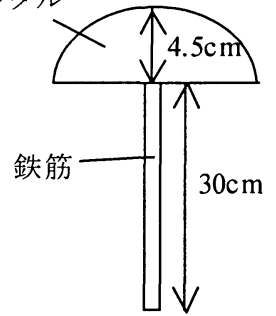

(b) 立面図
表-1 模擬石および実河床碟に付着する藻類量の比較

\begin{tabular}{|c|c|c|}
\hline & 模擬石 & 奉河床磻 \\
\hline 瀬3 & 39.3 & 36.3 \\
\hline 淵3 & 37.8 & 33.7 \\
\hline
\end{tabular}

(単位: mg.chl.a/m²)

図-2＼cjkstart観測に用いた模擬石

表-2 瀬と淵の水理特性

\begin{tabular}{|c|c|c|c|c|}
\hline & 平均水深 $\mathrm{H}(\mathrm{m})$ & 平均流速 $\mathrm{U}(\mathrm{m} / \mathrm{s})$ & フルード数 $\mathrm{Fr}=\mathrm{U} /(\mathrm{gH})^{1 / 2}$ & レイノルズ数 $\mathrm{Re}=\mathrm{UH} / \mathrm{v}$ \\
\hline 瀬 1 & 0.27 & 1.22 & 0.69 & $3.3 \times 10^{5}$ \\
\hline 瀬3 & 0.36 & 0.96 & 0.49 & $3.5 \times 10^{5}$ \\
\hline 淵1 & 0.31 & 0.71 & 0.41 & $2.2 \times 10^{5}$ \\
\hline 淵2 & 0.40 & 0.44 & 0.22 & $1.8 \times 10^{5}$ \\
\hline 淵3 & 0.59 & 0.55 & 0.23 & $3.2 \times 10^{5}$ \\
\hline 淵4 & 0.76 & 0.44 & 0.16 & $3.3 \times 10^{5}$ \\
\hline
\end{tabular}

を行った. また，8月 26 日 0pmに採水されたサンプ ル水に対しては, 分光光度計により植物の光合成 に重要となる可視光領域の光 $(660 \mathrm{~nm})$ の水中透過 率を测定した。

瀬と淵の付着藻類の一次生産特性をとらえるた め, 1997 年 7 月 18 日〜9 月 11 日（55日間）にかけ て以下の測定を行った。1997年7月 18 日に各瀬, 淵 に30 個ずつ（計 210 個）モルタルで作成した模擬石 を設置し,それらを 1 週間毎に3 個ずつ回収した。回 収された模擬石に付着した藻類を歯ブラシで剥が し取り，それに含まれるクロロフィル $\mathrm{a}$ 量を分光光 度計を用いた 3 波長法 ${ }^{16)}$ により測定し, 藻類量とし た. 模擬石の設置地点を図 -1 中に○印で示す．模 擬石の形状は，観測対象地の河床表面に見られる 礫を参考として，底面の直径を $12 \mathrm{~cm}$ とした半球を 押しつぶしたような形状（図-2）とし，底部に取 り付けられた鉄筋を河床に突き刺すことによって 河川内に固定した．表 -1 に，瀬 3 および淵 3 にお ける，模擬石と実河床碟表面のクロロフィル a 量の 比較（模擬石設置より 28 日後）を示す. 模擬石に 付着する藻類量は，実河川碟のそれよりも 1 割程度 大きな值を示している．模擬石はモルタルで作成 しているため，実河川磁より表面が粗く，その結 果, 藻類が付着し易くなり, このような違いが生じ たものと推察されるが，瀬と淵で同傾向・同程度の 過大評価であるため，両者の間の一次生産特性の 違いを抽出することは可能であるものと判断され る. 1997 年 8 月 27 日には, 碟周りの藻類の付着分
表 -3 観測全地点・観測期間平均栄養塩濃度

\begin{tabular}{|c|c|c|c|c|c|}
\hline $\begin{array}{c}\mathrm{NH}_{4}-\mathrm{N} \\
(\mathrm{mg} / \mathrm{l})\end{array}$ & $\begin{array}{c}\mathrm{NO}_{2}-\mathrm{N} \\
(\mathrm{mg} / \mathrm{l})\end{array}$ & $\begin{array}{c}\mathrm{NO}_{3}-\mathrm{N} \\
(\mathrm{mg} / \mathrm{l})\end{array}$ & $\begin{array}{c}\mathrm{T}-\mathrm{N} \\
(\mathrm{mg} / \mathrm{l})\end{array}$ & $\begin{array}{c}\mathrm{PO}_{4}-\mathrm{P} \\
(\mathrm{mg} / \mathrm{l})\end{array}$ & $\begin{array}{c}\mathrm{T}-\mathrm{P} \\
(\mathrm{mg} / \mathrm{l})\end{array}$ \\
\hline 0.044 & 0.043 & 2.7 & 2.8 & 0.088 & 0.088 \\
\hline
\end{tabular}

布を把握するため，瀬 3，淵 3 それぞれにおいて長 径 $15 \mathrm{~cm} \sim 20 \mathrm{~cm}$ の河床砅を 5 個採取して，その流れ に対して上流側の面, 頂部の面, 下流側の面のそれ ぞれに付着するクロロフィル a 量を測定した（藻 類採取面積: $5 \mathrm{~cm} \times 5 \mathrm{~cm}) .1997$ 年9月 11 日には，図一 1 中に示される瀬 3 および淵 3 の河床碟から付着藻 類を採取し，その種分析を行った。

\section{(2) 観測結果及び考察}

\section{a) 瀬と淵の水理特性}

各模擬石設置横断面における瀬と淵の水理量を 表 -2 に示す. 表中では付着藻類の生理活動に関連 する水理量として，日射の透過率に影響を与える 水深, 瀬, 淵といった流れ場の違いに関連する Froude 数, 流れ場の乱れの大きさを表す指標とし て Reynolds 数を示している.これらの水理量に加 えて，基質拡散に影響を与える藻類付着基盤近傍 の乱れや，藻類の付着し易さに影響を与える付着 面の粗さなどを表す水理的な指標が重要になるも のと思われるが，その詳細は現段階では明らかで 無い，また，瀬 2 は流速が大きく，地形測量が正確 に行えなかったため記載していない，瀬と淵を比 較すると，瀬ではフルード数が大きな值を示すこ 


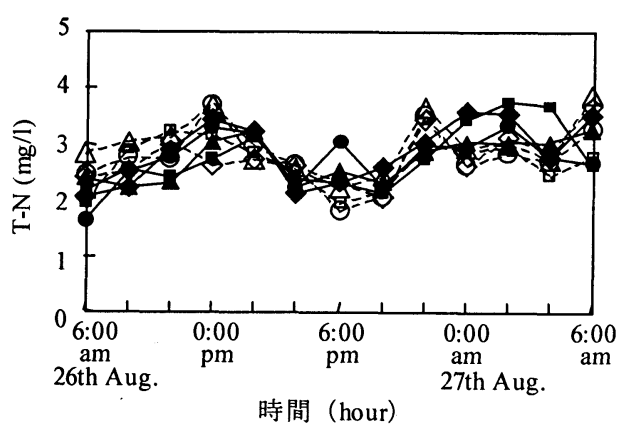

(a) 全窒素濃度

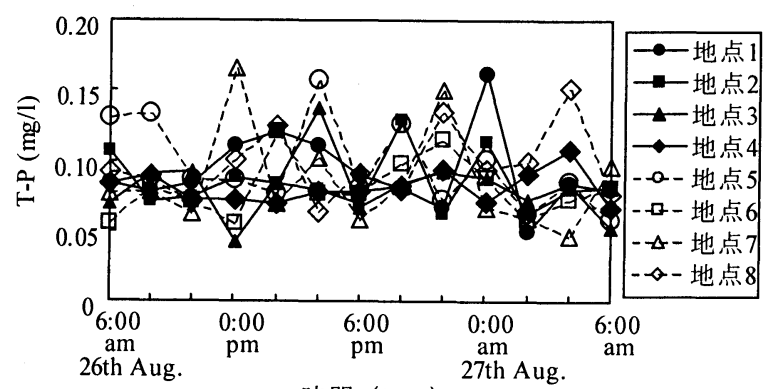

時間（hour）

(b) 全リン濃度

図 -3 全窒素・全リン濃度の時間変化

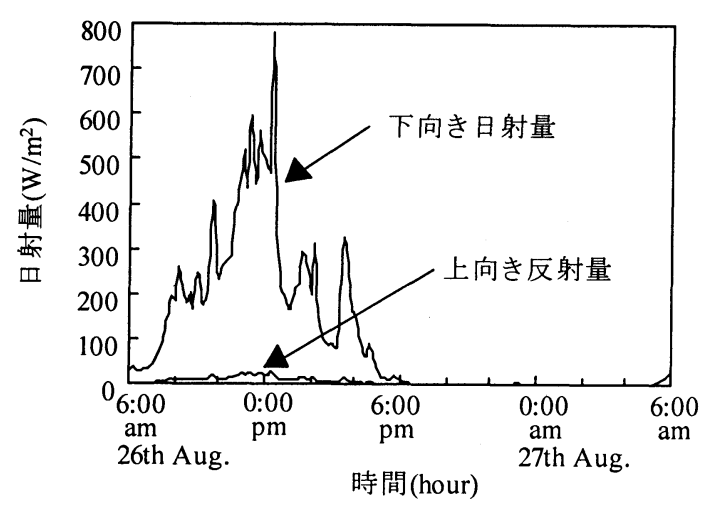

図-4 日射量

とが分かる．そのため瀬の中に存在する大きな礫 の背後では跳水による気泡の混入により局所的に 水表面が白濁している様子が観察され, 常流, 射流 の混在する流れが形成されていたものと思われる.

\section{b) 栄養塩の日変化}

栄養塩 $\left(\mathrm{NH}_{4}-\mathrm{N}, \mathrm{NO}_{3}-\mathrm{N}, \mathrm{NO}_{2}-\mathrm{N}, \mathrm{T}-\mathrm{N}, \mathrm{PO}_{4}-\mathrm{P}, \mathrm{T}-\mathrm{P}\right)$ の全地 点・観測期間（8月 26 日 $6 \mathrm{am} \sim 8$ 月 27 日 $6 \mathrm{am}$ ）平均 濃度を表 -3 に示す. 本観測地では, 後に示すよう に河川水中の溶存酸素が豊富であり, 全窒素, 全リ ンの殆どは最も酸化された形態である硝酸態窒素 やリン酸態リンとして存在している．観測対象地 の全窒素 / 全リン重量比は約 32 であり, 微生物体 内の典型的な窒素 / リン構成比表す Redfield 比（= 7.2） ${ }^{17)}$ と比較すると, リン制約となる環境下にある といえる.

全窒素 (T-N), 全リン (T-P) の全測定地点での日変 化を図 -3 に示す. 全窒素の日変化は 8 月 26 日正午 頃と 8 月 26 日 $10 \mathrm{pm}$ 以降に大きな值を示している. 一般的に住宅地などからの生活排水の影響を受け た河川区間においては污濁物負荷量のピークは 9am 〜 $11 \mathrm{am}$ 頃と $7 \mathrm{pm} \sim 9 \mathrm{pm}$ 頃の一日に 2 回出現すると 言われている ${ }^{18)}$. 本観測で見られた全窒素の変動
表-4 河床への日射の到達率

\begin{tabular}{|c|c|c|c|c|c|c|}
\hline & 瀬 1 & 瀬3 & 淵1 & 淵2 & 淵3 & 淵4 \\
\hline $\begin{array}{c}\text { 日射の到達率 } \\
(\%)\end{array}$ & 92.5 & 90.1 & 91.4 & 89.0 & 84.3 & 80.2 \\
\hline
\end{tabular}

はそれらの報告より 1 ～2 時間程位相が遅れている ものの, これらの変動は流域からの負荷変動に起 因しているものと考えられる.これに対して全リ ンの日変化には特徵的な変動は見られず, 0.06 $0.16 \mathrm{mg} / \mathrm{l}$ の間で不規則に変動している. 全窒素, 全 リン濃度ともに測定地点間の系統的な違いは見ら れず，瀬と淵の間には栄養塩環境の有意な違いは 無いものと判断される.

\section{c）日射及び溶存酸素濃度の日変化}

日射量の日変化を図 -4 に示す。日射量の $4 \%$ 程 度が水で反射しており，ほとんどが水中に透過し ている. 波長 $660 \mathrm{~nm}$ に対する河川水の吸光係数の計 測結果は $0.29 \mathrm{~m}^{-1}$ であり, 純水の值 $\left(0.28 \mathrm{~m}^{-1}\right)$ に近く, 観測対象水域の透明度が高いことが分かる。水中 の日射の透過特性と水深の関係をあらわす LambertBeer の光透過式 ${ }^{19)}$ は

$$
E / E_{0}=\exp (-\alpha D)
$$

で示される.ここに $E_{0}$ : 水面を水中に投下する日射 量 $\left(\mathrm{W} / \mathrm{m}^{2}\right), E$ : 水面からの深度 $D(\mathrm{~m})$ における日 射量 $\left(\mathrm{W} / \mathrm{m}^{2}\right), \alpha$ : 吸光係数 $\left(\mathrm{m}^{-1}\right)$. 式 (1) から得ら れる各瀬と淵の模擬石設置地点での河床への光の 到達率を表 -4 に示す. 最も水深の大きい淵 4 でも 日射の $80 \%$ 程度が河床に到達しており，いずれの 地点においても日射のほとんどが河床へ到達して いることが分かる．植物の光合成活動は光量（照 度）に依存するため, 日射量と照度の関係を明らか にする必要がある。エネルギ一の単位である日射 


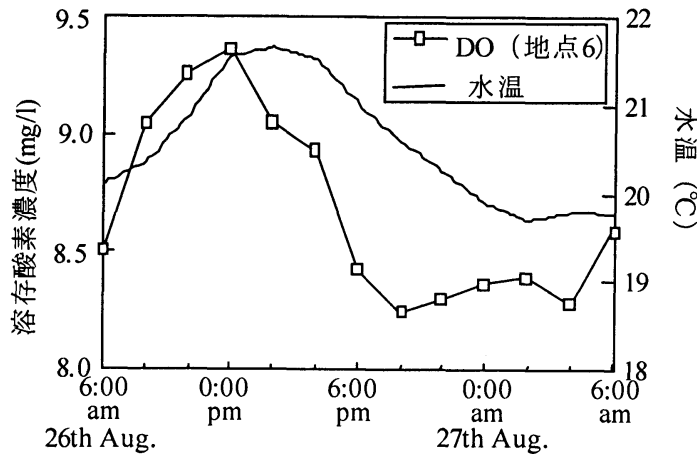

時間(hour)

図-5 溶存酸素濃度の日変化

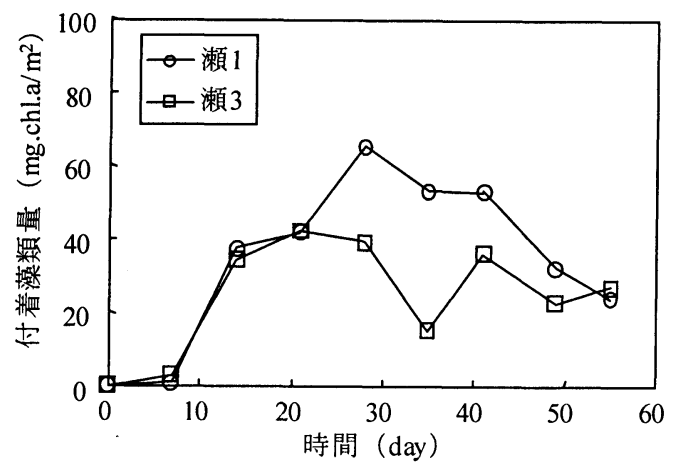

(a) 瀬

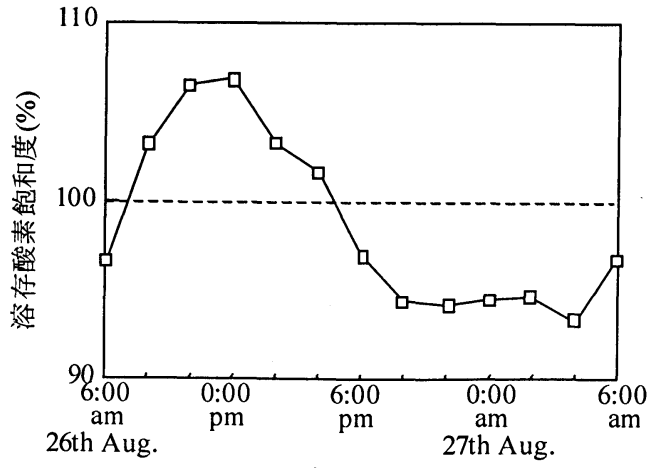

時間(hour)

図-6 溶存酸素飽和度の日変化

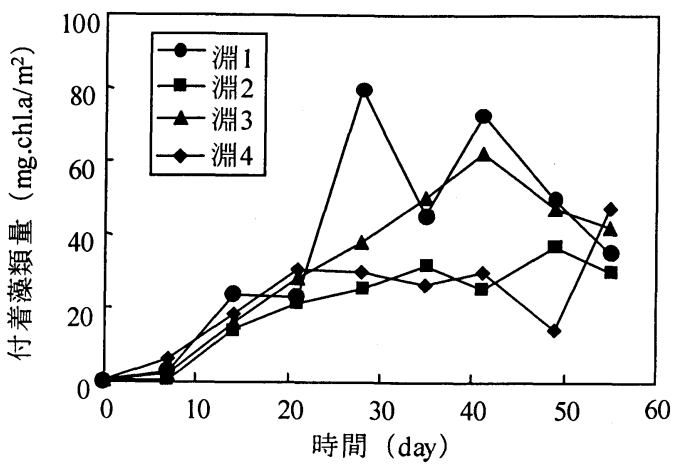

(b) 淵

図-7 河床付着藻類の増殖過程

量と光量である照度を完全に変換することは厳密 には不可能であるが，太陽光の場合には，両者の間 に近似的に次式 ${ }^{20)}$ が成り立つことが知られている.

$$
1 \mathrm{~W} / \mathrm{m}^{2}=103.41 \mathrm{ux}
$$

本観測では上述のように日射のほとんどが河床へ 到達しているので，水中を透過する際の波長毎の 吸光係数の違いは無視できるものと考えられる. 従って上記の近似的な関係は河床付近に拡張する ことが可能である．式(1)，(2)を用いて算定した河 床の照度は日中 $40 \sim 60 \mathrm{klux}$ 程度であった. 淡水域 に生息する植物プランクトンや付着藻類は, 約 20klux 以上の光量があると活発な光合成活動を行う

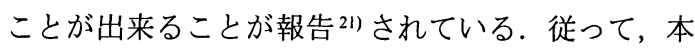
観測対象地においては, 日中は瀬, 淵に関わらず光 合成を行うのに十分な光量が確保されていると考 えられる。

水温及び溶存酸素濃度の日変化を図 -5 に示す. 溶存酸素濃度は, 栄養塩濃度と同様に, 地点間の有 意な違いが見られなかったため, 図中では地点 6 の 結果のみを示している。水温変化は水の熱容量の
表-5 河床礫周囲の付着藻類分布

\begin{tabular}{|c|c|c|c|c|}
\hline 計測日 & 計測地点 & 上流側の面 & 頂部の面 & 下流側の闻 \\
\hline \multirow{2}{*}{ 27th Aug. } & 瀬3 & 7.0 & 35.7 & 33.6 \\
\cline { 2 - 5 } & 淵3 & 20.3 & 19.9 & 19.1 \\
\hline
\end{tabular}

(単位 : mg.chl.a/ $\mathrm{m}^{2}$ )

ため日射のピーク（正午）から位相が遅れ，2pm 頃 にピーク值を示している. 水温の日変化を考虑し て算出した溶存酸素の飽和度の日変化を図 -6 に示 す. 8 月 26 日 $8 \mathrm{am}$ 頃〜 8 月 26 日 $5 \mathrm{pm}$ 頃における溶存 酸素は過飽和状態であるが，それにもかかわらず， 午前中には水中の溶存酸素濃度が増加している。 このような増加が生じるには, 過飽和に逆らう強 制的な曝気や付着藻類による光合成によって水中 に酸素が供給されていなければならない。観測期 間中の水理量は殆ど変化していなかったので, こ の様な溶存酸素濃度の増加は観測区間上流域から 観測対象地の間で生じる藻類の光合成活動による ものと考えられる.

\section{d) 付着藻類の增殖過程}

図-7 (a)，(b)に瀬，淵における模擬石に付着した 藻類の増殖過程を示寸.一般に生物の増殖は, 初期 
表-6 瀬と淵の付着藻類種

\begin{tabular}{|c|c|c|c|c|c|c|c|}
\hline No. & 植物門 & 網 & 目 & 種名 & 瀬 3 & 淵3 & $\begin{array}{c}\text { 細胞の大きさ } \\
(\mu \mathrm{m})\left({ }^{*} 2\right)\end{array}$ \\
\hline 1 & \multirow[t]{2}{*}{ 藍色門 } & \multirow[t]{2}{*}{ 藍藻網 } & \multirow[t]{2}{*}{ 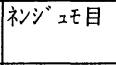 } & Homoeothrix spp. $\left({ }^{*} 1\right)$ & 19 & 19 & $2.5 \sim 15,50 \sim 600$ \\
\hline 2 & & & & Oscillatoria spp. & 73 & 66 & $2 \sim 3, \quad 2 \sim 8$ \\
\hline 3 & \multirow[t]{16}{*}{ 不等毛門 } & \multirow{16}{*}{ 珪藻綱 } & 中心目 & Melosira granulata & & & $8 \sim 35$ \\
\hline 4 & & & \multirow[t]{15}{*}{ 羽状目 } & Diatoma vulgaris & & & $45 \sim 60, \quad 10 \sim 18$ \\
\hline 5 & & & & Synedra inaequalis & & & $35 \sim 90,7.5 \sim 9$ \\
\hline 6 & & & & Synedra spp. & & 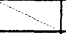 & \\
\hline 7 & & & & Cocconeis placentula & & & $20 \sim 60,10 \sim 40$ \\
\hline 8 & & & & Achnanthes lanceolata & 4 & 8 & $10 \sim 30,4 \sim 8$ \\
\hline 9 & & & & Achnanthes spp. & & & \\
\hline 10 & & & & Navicula gregaria & & & \multirow{3}{*}{$13 \sim 40,5 \sim 10$} \\
\hline 11 & & & & Navicula gregaria & & & \\
\hline 12 & & & & Navicula spp. & & & \\
\hline 13 & & & & Pinnularia viridis & & & $50 \sim 150,10 \sim 25$ \\
\hline 14 & & & & Cymbella turgidula & & & $25 \sim 50,10 \sim 15$ \\
\hline 15 & & & & Gomphonema sphaerophorum & & & \\
\hline 16 & & & & Gomphonema spp. & & & \\
\hline 17 & & & & Nitzschia fruticosa & 1 & & $5 \sim 30,2.5 \sim 3.5$ \\
\hline 18 & & & & Nitzschia palea & 3 & 4 & $20 \sim 65,3 \sim 5$ \\
\hline 19 & \multirow[t]{2}{*}{ 緑藻門 } & \multirow[t]{2}{*}{ 緑藻網 } & 力エトフォラ目 & Stigeoclonium spp. & - & 1 & $10 \sim 17,10 \sim 30$ \\
\hline 20 & & & クロロコックム目 & Scenedesmus spp. & & & $2 \sim 9,7 \sim 35$ \\
\hline
\end{tabular}

(表中の数值は細胞数に基づく百分率 (単位\%). 表中の空欄は種の存在が確認されたものの, 細胞数が $0.5 \%$ 以下で あった種であり，斜線部は存在が確認されなかった種を表す. $\left({ }^{*} 1\right)$ Homoeothrix spp. は糸状体を1と計数している. (*2)Homoeothrix spp. については, 文献22)より属内の 4 つの種の基部および糸状体の全長の範囲を示しており，他の種 に関しては, 文献 23)より, 球形のものに関してはその直径を, その他のものに関しては細胞直径と細胞長さ（珪藻綱 羽状目については殻長と殼幅)を記している.)

に指数関数的に増加し，栄養分や環境条件の制約 により，増殖が低下すると言われており，その様子 が本観測でも捉えられている．瀬と淵の増殖過程 の違いに着目すると, 瀬では模擬石設置後 7〜14 日 の間に $40 \mathrm{mg} . \mathrm{chl} . \mathrm{a} / \mathrm{m}^{2}$ 程度まで急速に増殖するが, 淵 では30日〜40日後付近まで緩やかに増殖している ことが分かる．前述のように，観測対象とした瀬と 淵では河床面での日射量, 栄養塩濃度に有意な違 いは見られなかった，従って。このような増殖初期 の生産活性の違いは水理特性の違いに起因してお り, 流速や摩擦速度が大きい瀬の方が初期の一次 生産活性が高いことが分かる。一方, 増殖が十分に 進行した模擬石設置から 40 日後以降の藻類量に関 しては, 值のばらつきが大きく, 瀬と淵の間で系統 的な違いは見られなかった。

実河床礧表面の流れに対して上流側の面, 頂部 の面, 下流側の面のそれぞれに付着する藻類量を 表 -5 に示す．淵の藻類は砅全面にほぼ一様に付着 しているのに対して, 瀬では上流側の面に比べて 頂部および下流側の面に多く付着している.

以上の結果を総合すると, 瀬と淵の藻類の増殖 · 生産過程の違いに関して以下のことが推論される. 淵では藻類の生産活性が低く, 緩やかに現存量を 增加させながら, 河床磁の全面へと繁茂が進行し ていく. 一方, 瀬では藻類の生産活性が高く, それ らが増殖の初期段階において河床礫の頂部の面,
下流側の面に付着し, 現存量の急速な増加を生じ させる. しかし, 藻類が付着できる面積が限定され ているため, 増殖の終期における藻類量では淵と の間に系統的な違いが見られなかったものと考え られる。

\section{e) 藻類の種組成}

表 -6 に付着藻類の種分析結果を示す. 表中の数 值は計測細胞数の百分率で示しており, 表中の空 欄部分は存在は確認されたものの, 細胞数が $0.5 \%$ 以下であった種であり，斜線部は検出されなかっ た種を表している，また，藍藻綱の Homoeothrix は 細胞境界が明確に判断できなかったため, 糸状体 を 1 として計数している. 観測対象域では, 細胞数 としては藍藻綱が圧倒的に優占しており, 出現種 数としては珪藻綱が最も多い. 本観測地で細胞数 に関して優占的に見られた藍藻綱Oscillatoria は系 状体の藻類であり, 観測期間中の流量変動が小さ かったため, Hoagland et al. ${ }^{2)}$ が報告しているような 単細胞型の藻類から糸状体藻類への典型的な種の 遷移が生じたものと推察される．瀬と淵の種組成 の違いに着目すると, 流速の大きな瀬の方が系状 体藍藻綱 (Homoeothrix spp., Oscillatoria spp.) の優 占率が若干大きく，このことは後に示す室内実験 の結果と定性的に一致する.

種組成の違いが藻類一次生産力に与える影響に ついては，各種毎の生産特性が未知である現段階 
表-7 実験水理条件

\begin{tabular}{|c|c|c|c|c|c|c|}
\hline \multirow{2}{*}{ 実験ケース } & 水路番号 & 水路床勾配 & $\begin{array}{c}\text { 断面平均流速 } \\
\mathrm{U}(\mathrm{cm} / \mathrm{s})\end{array}$ & $\begin{array}{c}\text { 断面平均水深 } \\
\mathrm{H}(\mathrm{cm})\end{array}$ & $\begin{array}{c}\text { フルード数 } \\
\mathrm{Fr}=\mathrm{U} /(\mathrm{gH})\end{array}$ & $\begin{array}{c}\text { レイノルズ数 } \\
\mathrm{Re}=\mathrm{UH} / \mathrm{v}\end{array}$ \\
\hline \multirow{4}{*}{ Case1 } & 水路 1 & $1 / 500$ & 9 & 3.5 & 0.15 & $3.2 \times 10^{3}$ \\
\cline { 2 - 7 } & 水路2 & $1 / 285$ & 13 & 2.7 & 0.25 & $3.5 \times 10^{3}$ \\
\cline { 2 - 7 } & 水路3 & $1 / 138$ & 51 & 1.8 & 1.2 & $9.2 \times 10^{3}$ \\
\cline { 2 - 7 } & 水路4 & $1 / 68$ & 71 & 1.5 & 1.9 & $1.1 \times 10^{4}$ \\
\hline \multirow{3}{*}{ Case2 } & 水路1 & $1 / 500$ & 8 & 8.1 & 0.09 & $6.5 \times 10^{3}$ \\
\cline { 2 - 7 } & 水路2 & $1 / 285$ & 12 & 9.8 & 0.12 & $1.2 \times 10^{4}$ \\
\cline { 2 - 7 } & 水路3 & $1 / 138$ & 33 & 8.2 & 0.37 & $2.7 \times 10^{4}$ \\
\cline { 2 - 7 } & 水路4 & $1 / 68$ & 40 & 8.5 & 0.44 & $3.4 \times 10^{4}$ \\
\hline
\end{tabular}

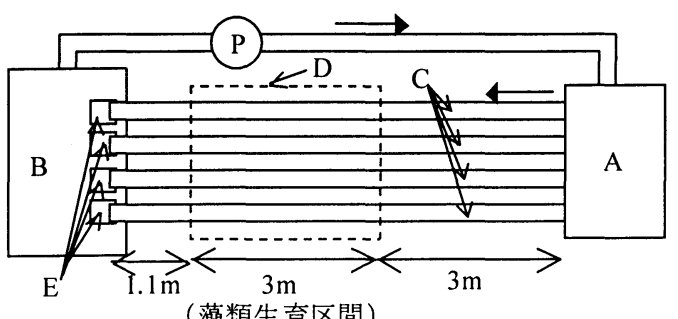

（藻類生育区間）

(a) 平面図

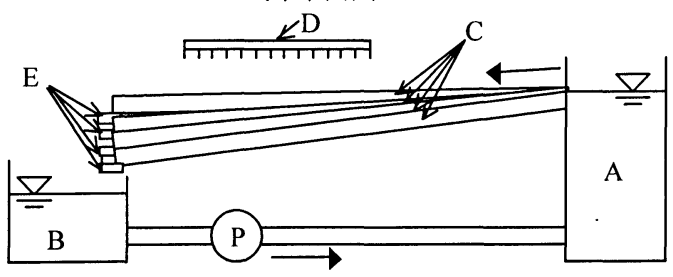

(b) 立面図

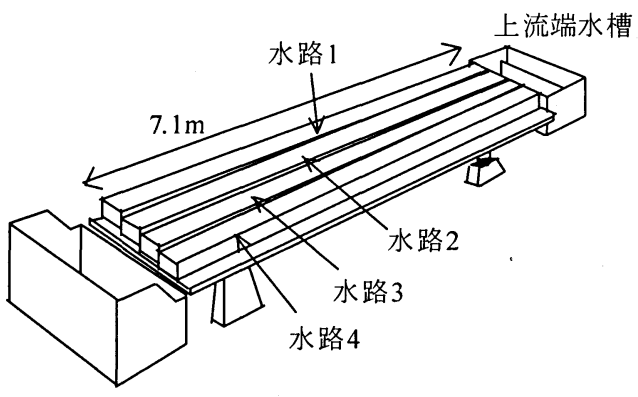

下流端水槽

(c) 鳥瞰図
A：上流端水槽
B : 下流端水槽
$\mathrm{C}:$ 水路 (4本)
D：照明
$\mathrm{E}$ : ネット
$\mathrm{P}:$ ポンプ

図-8 実験水路図

において, 明確な結論は得られていない.これにつ いては, 今後の河床付着藻類の一次生産特性を解 明していく上で重要な課題である.

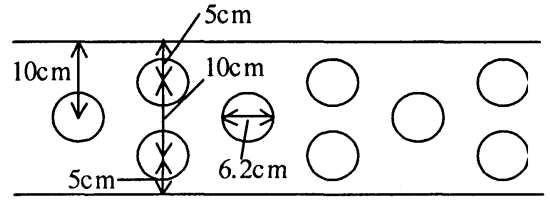

(a) 平面図

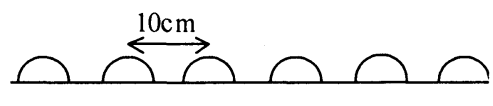

(b) 立面図

図-9 水路床上の半球状突起の配置 (Case2)

\section{3. 室内実験}

現地観測では捉えきれない付着藻類の増殖過程 や剥離形態の詳細な特性を把握するため, 室内実 験を実施した。実験では, 光量, 栄養塩濃度, 水温 を一定に保ち, 水理条件の相違による一次生産特 性の違いを抽出することを目的とした.

\section{(1) 実験方法}

図-8（a），(b)，(c)に実験に用いた水路群の平面 図，立面図，鳥瞰図を示す，実験水路群は水路床勾 配の異なる 4 本の開水路から構成されており，そ れらは上流端水槽および下流端水槽を共有してい る.このことにより, 各水路には水理条件のみが異 なり，水温・水質に関して全く同質の水が循環する こととなる。水路はアクリル製で長さ $710 \mathrm{~cm}$, 幅 $20 \mathrm{~cm}$ である．実験は，最も単純な水理条件の場合 として平坦床（Case1）および碩床河川を模して底 面に直径 $6.2 \mathrm{~cm}$ の半球状の突起を千鳥状に配置した 場合（Case2，図-9）の 2 ケースについて実施した. 各実験ケースにおける水理条件を表 -7に示す．水 路床表面は藻類が付着しやすいようにサンドペー パー（40 番）で粗さを付けた。また，各水路の下 流端にはネットを取り付け，流れのせん断力や藻 類の生理作用によって水路床から剥離した藻類を 
表-8 実験水質記録

\begin{tabular}{|c|c|c|c|c|c|c|c|c|}
\hline $\begin{array}{l}\text { 実験 } \\
\text { ケース }\end{array}$ & $\begin{array}{l}\text { 計測日 } \\
\text { (実験開始 } \\
\text { 後日数) }\end{array}$ & $\begin{array}{l}\text { 水温 } \\
\left({ }^{\circ} \mathrm{C}\right)\end{array}$ & $\begin{array}{l}\mathrm{NH}_{4}-\mathrm{N} \\
(\mathrm{mg} / \mathrm{l})\end{array}$ & $\begin{array}{l}\mathrm{NO}_{2}-\mathrm{N} \\
(\mathrm{mg} / \mathrm{l})\end{array}$ & $\begin{array}{l}\mathrm{NO}_{3}-\mathrm{N} \\
(\mathrm{mg} / \mathrm{l})\end{array}$ & $\begin{array}{c}\mathrm{T}-\mathrm{N} \\
(\mathrm{mg} / \mathrm{l})\end{array}$ & $\begin{array}{l}\mathrm{PO}_{4}-\mathrm{P} \\
(\mathrm{mg} / \mathrm{l})\end{array}$ & $\begin{array}{c}\mathrm{T}-\mathrm{P} \\
(\mathrm{mg} / \mathrm{l})\end{array}$ \\
\hline \multirow{12}{*}{ Case 1} & 0 & 28.5 & 0.09 & 0.002 & 3.2 & 3.3 & 0.17 & 0.20 \\
\hline & 3 & 27.4 & 0.29 & 0.051 & 2.4 & 2.7 & 0.09 & 0.10 \\
\hline & 7 & 28.5 & 0.22 & 0.081 & 2.2 & 2.5 & 0.07 & 0.16 \\
\hline & 10 & 29.5 & 0.93 & 0.112 & 1.4 & 2.4 & 0.05 & 0.05 \\
\hline & 13 & 31.0 & 0.02 & 0.223 & 2.7 & 2.9 & 0.10 & 0.12 \\
\hline & 16 & 29.5 & 0.08 & 0.285 & 2.5 & 2.9 & 0.16 & 0.18 \\
\hline & 23 & 29.5 & 0.37 & 0.011 & 2.7 & 3.1 & 0.17 & 0.18 \\
\hline & 31 & 29.0 & 0.09 & 0.006 & 3.6 & 3.7 & 0.20 & 0.22 \\
\hline & 39 & 27.0 & 0.17 & 0.020 & 3.4 & 3.6 & 0.18 & 0.18 \\
\hline & 46 & 29.7 & 0.07 & 0.004 & 2.4 & 2.5 & 0.16 & 0.16 \\
\hline & 53 & 26.6 & 0.15 & 0.003 & 2.6 & 2.8 & 0.11 & 0.15 \\
\hline & 60 & 29.1 & 0.05 & 0.007 & 2.7 & 2.8 & 0.13 & 0.14 \\
\hline \multirow{8}{*}{ Case2 } & 0 & 24.5 & 0.05 & 0.007 & 3.3 & 3.4 & 0.14 & 0.16 \\
\hline & 6 & 24.1 & 0.21 & 0.023 & 2.6 & 2.8 & 0.08 & 0.11 \\
\hline & 11 & 24.7 & 0.32 & 0.116 & 2.8 & 3.2 & 0.15 & 0.18 \\
\hline & 18 & 23.8 & 0.03 & 0.213 & 2.3 & 2.5 & 0.17 & 0.18 \\
\hline & 25 & 24.6 & 0.08 & 0.032 & 3.1 & 3.2 & 0.11 & 0.14 \\
\hline & 32 & 24.8 & 0.12 & 0.004 & 2.7 & 2.8 & 0.18 & 0.22 \\
\hline & 40 & 24.5 & 0.01 & 0.016 & 2.8 & 2.8 & 0.11 & 0.14 \\
\hline & 49 & 24.6 & 0.01 & 0.003 & 2.9 & 2.9 & 0.15 & 0.17 \\
\hline
\end{tabular}

捕捉した。ネット孔径は, 既往の生物膜の実験 ${ }^{24)}$ で 剥離生物捕捉に用いられたネット孔径を参考にし て $150 \mu \mathrm{m}$ とした.

水路上方には光合成活動に必要となる光を与え るため, 450Wの白熱レフランプ (RF110V450WH, 松 下電器(侏製) を 8 個設置した。昼夜の別はタイマー で制御しており，1 日当たりランプ点灯時間は 16 時間とした．ランプ点灯中の水路床における照度 は約 20klux であり，それにより与えられる 1 日当た りの光エネルギーは $860 \mathrm{~J} / \mathrm{cm}^{2} / \mathrm{day}$ である.この值は 関東域の地表が春期に受ける太陽光エネルギーの 可視・紫外部に相当するものであり，藻類の生育に 十分な光量であるものと判断される．藻類の生育 区間は，上流端より流入した流れが十分発達し，等 流状態に達した区間（水路上流端より $300 \mathrm{~cm} 〜$ $600 \mathrm{~cm}$ の間）に限定し，他の区間は水路を暗幕で覆 い光を与えなかった. 光が与えられた区間の水路 床は流下方向 $20 \mathrm{~cm} \times$ 横断方向 $19.8 \mathrm{~cm}$ のプレート（計 15 枚）に区切られており，藻類量の計測時には各 プレートを取り外すことが出来るようになってい る.

実験期間中の水質記録を表 -8 に示す：実験水に は水道水を用いており，その中に多摩川の河川水 を $3.0 \mathrm{~kg}$ 混入している. 栄養塩濃度 $\left(\mathrm{NH}_{4}-\mathrm{N}, \mathrm{NO}_{2}-\mathrm{N}\right.$, $\left.\mathrm{NO}_{3}-\mathrm{N}, \mathrm{T}-\mathrm{N}, \mathrm{PO}_{4}-\mathrm{P}, \mathrm{T}-\mathrm{P}\right)$ に関して，3〜8日間隔で 実験水の濃度計測を行い，表 -2 で示した多摩川観 測時の水質と比較して栄養塩濃度が著しく低下し ている場合には，窒素に関しては $\mathrm{KNO}_{3}$, リンに関 しては $\mathrm{K}_{2} \mathrm{HPO}_{4}$ を添加した，各栄養塩項目の測定法
は，分光光度計を用いた比色法 ${ }^{15)}$ である．また，長 期間の実験水の循環によって付着藻類の生育に悪影 響のある代謝物が蓄積することや，窒素・リン以外 の微量栄養元素が成長の制約因子となることを防く ため，各実験期間中に 3 回，全ての実験水の取り替 えを行った. 水温は水質分析時に簡易多項目水質計 （U-10，(株）堀場製作所製）を用いて計測した. Case の実験時期は 7 月下旬から9月下旬であり実験水の 水温は $27 \sim 30^{\circ} \mathrm{C}$ 間で変動していたが, 藻類の生 育を妨げるような著しい水温低下 ${ }^{6)}$ は見られなかっ たため，水温調節は行わなかった，Case2 の実験時 期は 11 月上旬から 1 月上旬であったので，実験水の 水温低下を防ぐため，投げ込み式ヒーター （BWA1115，（株）JET 製）とサーモスタット（DG2100 ，（株）HAKKO製）を用いて水温を $24 \pm 1^{\circ} \mathrm{C}$ 範 囲に保った。2 ケース共に実験時の水温は，多摩川 での観測時の水温 $\left(19^{\circ} \mathrm{C} \sim 21^{\circ} \mathrm{C}\right)$ と比較して高く, $20^{\circ} \mathrm{C}$ 前後の水温を好む珠藻より緑藻や藍藻の生育に 有利な水温条件 6) となった。このような水温の違い は, 後に示される実験水路内の藻類種が, 現地河川 における藻類種と異なっていることの一因となって いるものと考えられる，従って，本実験の結果を現 地河川の付着藻類の生理特性と直接比較を行うこと は困難であるが，4つの水路間の水温・水質が等し いことから，水路間の水理特性の違いによる一次生 産特性の違いを抽出するのには十分であるものと判 断される。

藻類量の計測は以下の手順で行った．藻類の増殖 が活発に行われる実験開始から20日間程度は3日〜 


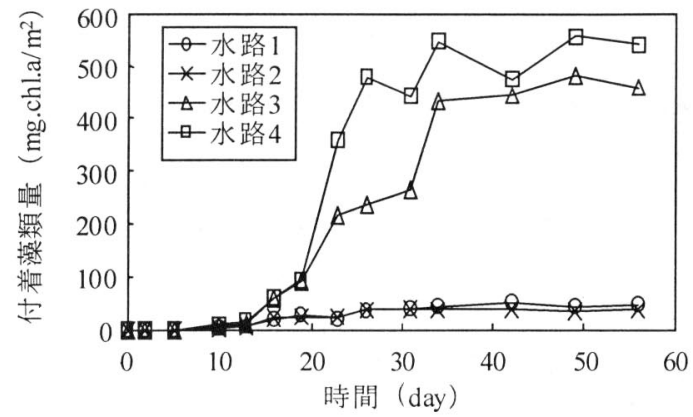

図-10 平坦水路床上の藻類の増殖過程 (Case1)

6 日間隔で，それ以降は約 1 週間間隔で，河床に設 置したプレートを 1 枚ずつ取り出し，それに付着 した藻類を歯ブラシで剥がし取った。剥がし取っ た藻類のクロロフィル a 量を 3 波長法 ${ }^{16)}$ で計測し た。 また, 藻類量の計測日には各水路下流端に設置 したネット上に捕捉されている藻類を回収し，そ れらのクロロフィル a 量の計測を行うことにより 剥離量を求めた。 また，Case1，Case2 ともに増殖の 初期段階および増殖がある程度進行した段階にお いて，藻類の種分析を実施した（Case 1：実験開始 より 5 日後および 34 日後, Case2 : 実験開始より 13 日後㧍よび 27 日後)

\section{（2）実験結果 1 -平坦水路床一}

\section{a) 藻類現存量およびー次生産力}

Case 1 に㧍ける付着藻類現存量の時系列变化を 図-10に示す．增殖の初期段階において各水路の藻 類現存量が指数関数的に増加し, その後, 栄養塩や 環境条件の制約によって増殖が低下するという， 一般的な生物の増殖過程が見られる。水路間の違 いに関しては，水路 $1 ， 2$ と比較して水路 3，4では 実験開始後 15 日目付近から著しく大きい増殖が生 じ, 実験終了時には水路 1，2の 10 倍程度の現存量 を示している. 本実験においては, 光強度, 水温, 栄養塩濃度は全ての水路で全く同一であることか ら,このような一次生産力の違いは，水理特性の違 いによって生じたものであり, 流速や底面付近の 乱れが大きな水路ほど一次生産力が高くなること が推定される。流れが一次生産力に与える影響に ついては，(1)流れの違いにより藻類種組成が変化 し, 種の生産活性の違いにより一次生産力が変化 する，(2)水理特性の違いにより藻類膜内部および 近傍の基質の拡散能が変化し, その結果, 一次生産 力が変化する，といった二つの要因が考えられる. しかし, 現段階では, 各藻類種の生産特性が解明さ れていないため, どちらの要因がより支配的で

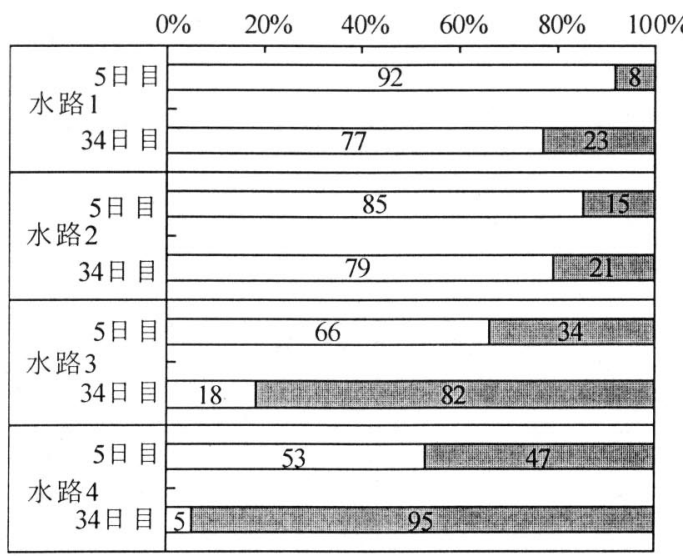

口単細胞・群体 四系状体

図-11 単細胞・群体型藻類と系状体藻類の割合 (Case1)

あったかについては不明である。

\section{b) 藻類の種組成}

表 -9 (a)，(b) に実験開始後 5 日目及び 34 日目にお ける付着藻類種の分析結果を示す. 種分析の表示 は, 現地観測と同様に同定細胞数の百分率で示し てあり，表中の空闌部分は存在が確認されたもの の $0.5 \%$ 以下の種, 斜線部は検出されなかった種を 示している. 表中に示されている通り, 藻類の細胞 の大きさは，種間で大きな差があり，細胞の大きさ を考慮に入れると，Homoeothrix の優占率がさらに 増加するものと思われる，従って，細胞数に基づく 百分率からは藻類量としての種構成を正確に把握 することは出来ない，しかし，藻類種毎の藻類量を 計測することが困難である現段階において，水路 内で多く見られたいくつかの種に限定し定性的な 大小関係を検討することは可能であり，かつ有益 であると思われることから，本論文では細胞数に 基づく百分率を用いて藻類の種構成を検討するこ ととする．実験開始より 5 日後の時点では，全ての 水路において緑藻綱 Scenedesmus の細胞数が最も大 きくなっているが，34 日後には藍藻綱の Chroococcusu や Homoeothrix が優占的に生育してい ることが分かる．藍藻綱の優占率は流速の大きな 水路ほど大きくなっており, 藻類現存量が著しく 大きくなる水路 3，4 では細胞数に基づく種構成に おいて，80\%以上が藍藻綱で占められている。

付着藻類はその形態的特徵として, 系状体のも のと単細胞あるいは群体となって繁茂するものが 存在し，それぞれによって流水からの影響の受け 方が異なるものと推察される。ここでは，実験水路 中の藻類を系状体とその他のもの（以下，単細胞 • 群体と称す）に分類した（図-11）。これらの割合 は各形態の藻類量に関する割合では無く，細胞数 
表-9 平坦水路床上に生育する藻類の種分析結果

(a) 実験開始より 5 日後

\begin{tabular}{|c|c|c|c|c|c|c|c|c|c|}
\hline No. & 植物門 & 網 & 目 & 種名 & 水路 1 & 水路 2 & 水路 3 & 水路 4 & $\begin{array}{c}\text { 細胞の大きさ } \\
(\mu \mathrm{m})\left({ }^{*} 2\right) \\
\end{array}$ \\
\hline 1 & ユーグレナ植物門 & & & Trachelomonus sp. & 25 & 7 & 2 & $\infty$ & $8 \sim 30, \quad 8 \sim 25$ \\
\hline 2 & 藍色門 & 藍䔉網 & クロオコックス目 & Chroococcusu sp. & 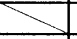 & 2 & $-\infty$ & 2 & $8 \sim 32$ \\
\hline 3 & & & 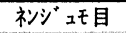 & Homoeothrix spp. $\left({ }^{*} 1\right)$ & 6 & 15 & 14 & 47 & $2.5 \sim 15,50 \sim 600$ \\
\hline 4 & & & & Calothrix sp. & 1 & & & & $5 \sim 10$ \\
\hline 5 & & & & Phormidium sp. & 1 & & $\infty$ & 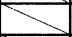 & $0.8 \sim 9$ \\
\hline 6 & & & 仸ゴ神目 & Westella sp. & $\infty$ & 7 & $\infty$ & $\mathrm{N}$ & \\
\hline 7 & 不等毛門 & 珪藻網 & 中心目 & Stephanodiscus sp. & & 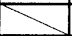 & 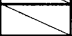 & 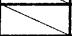 & $7 \sim 16$ \\
\hline 8 & & & & Bacillaria pardoxa & 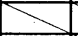 & $>$ & $\rightarrow$ & & \\
\hline 9 & & & 羽状目 & Achnanthes convergens & 1 & $\rightarrow$ & & & $10 \sim 25, \quad 4 \sim 45$ \\
\hline 10 & & & & Achnanthes minutissima & 0 & S & & & $5 \sim 25, \quad 3 \sim 4$ \\
\hline 11 & & & & Achnanthes minutissima saprophila & 1 & $\infty$ & & & $8 \sim 15, \quad 3 \sim 3.5$ \\
\hline 12 & & & & Cocconeis placentula lineata & -1 & 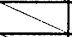 & 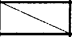 & & $20 \sim 60, \quad 10 \sim 40$ \\
\hline 13 & & & & Fragilaria crotonensis & $1]$ & 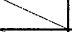 & & & $40 \sim 170, \quad 2 \sim 4$ \\
\hline 14 & & & & Gomphonema parvulum & 2 & 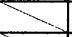 & & & $10 \sim 40, \quad 5 \sim 8$ \\
\hline 15 & & & & Nitzschia filiformis conferta & 6 & 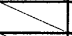 & 1 & 2 & $30 \sim 70, \quad 4.5 \sim 5$ \\
\hline 16 & & & & Nitzschia hantzschiana & & 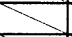 & $\longrightarrow$ & $\infty$ & $12 \sim 40, \quad 3 \sim 4$ \\
\hline 17 & & & & Synedra ulna & & $\infty$ & $\infty$ & $\infty$ & $50 \sim 350, \quad 5 \sim 9$ \\
\hline 18 & & & & Rhoicosphenia abbreviata & & $>$ & -2 & 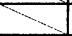 & $12 \sim 70, \quad 4 \sim 8$ \\
\hline 19 & 緑藻門 & 緑藻網 & クロ䏒目 & Scenedesmus acutus & 30 & 40 & 22 & 15 & \multirow{5}{*}{$2 \sim 9, \quad 7 \sim 35$} \\
\hline 20 & & & & Scenedesmus acutus f. alteraus & 15 & 8 & 14 & 3 & \\
\hline 21 & & & & Scenedesmus arcuatus & 11 & 15 & 38 & 28 & \\
\hline 22 & & & & Scenedesmus sp. & & 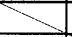 & 10 & 2 & \\
\hline 23 & & & クロロサ川キナ目 & Tetrachlorella spp. & $>$ & 7 & 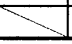 & 3 & \\
\hline
\end{tabular}

(b) 実験開始より 34 日後

\begin{tabular}{|c|c|c|c|c|c|c|c|c|c|}
\hline No. & 植物門 & 網 & 目 & ·種名 & 水路 1 & 水路2 & 水路3 & 水路 4 & $\begin{array}{c}\text { 細胞の大きさ } \\
(\mu \mathrm{m}) \quad(* 2) \\
\end{array}$ \\
\hline 1 & ユーグレナ植物門 & & & Trachelomonus sp. & 2 & & & & $8 \sim 30,8 \sim 25$ \\
\hline 2 & 藍色門 & 藍藻網 & 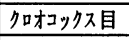 & Chroococcusu sp. & 11 & 49 & 16 & & $8 \sim 32$ \\
\hline 3 & & & \multirow[t]{4}{*}{ 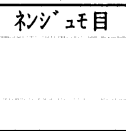 } & Homoeothrix spp. $\left({ }^{*} 1\right)$ & 16 & 20 & 82 & 95 & $2.5 \sim 15,50 \sim 600$ \\
\hline 4 & & & & Lyngbia putealis & 1 & 1 & & & \multirow{2}{*}{$2 \sim 18$} \\
\hline 5 & & & & Lyngbia aerugineo-coerulea & 5 & 1 & & 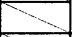 & \\
\hline 6 & & & & Scytonema $\mathrm{sp}$. & 10 & 1 & 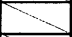 & 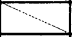 & \\
\hline 7 & & & カマエシフォン目 & Chamaesiphon $\mathrm{sp}$. & 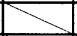 & 4 & 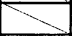 & & \\
\hline 8 & \multirow[t]{8}{*}{ 不等毛門 } & \multirow[t]{7}{*}{ 珪藻網 } & \multirow[t]{7}{*}{ 羽状目 } & Achnanthes convergens & $\infty$ & $\infty$ & - & & $10 \sim 25, \quad 4 \sim 4.5$ \\
\hline 9 & & & & Achnanthes minutissima & 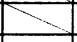 & 2 & $\sum$ & & $5 \sim 25, \quad 3 \sim 4$ \\
\hline 10 & & & & Achnanthes minutissima saprophila & 14 & 12 & & & $8 \sim 15,3 \sim 3.5$ \\
\hline 11 & & & & Fragilaria crotonensis & W & 2 & & & $40 \sim 170, \quad 2 \sim 4$ \\
\hline 12 & & & & Gomphonema parvulum & 0 & 1 & & & $10 \sim 40, \quad 5 \sim 8$ \\
\hline 13 & & & & Navicula minima & 0 & 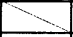 & $\mathrm{S}^{-1}$ & & $5 \sim 18, \quad 3 \sim 4.5$ \\
\hline 14 & & & & Nitzschia filiformis conferta & 18 & 6 & & 1 & $30 \sim 70, \quad 4.5 \sim 5$ \\
\hline 15 & & 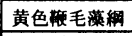 & オク吼ス目 & Dinobryon sp. & 1 & 2 & 2 & 2 & $7 \sim 14, \quad 30 \sim 50$ \\
\hline 16 & \multirow[t]{8}{*}{ 緑澡門 } & \multirow[t]{7}{*}{ 緑藻網 } & クロロコックム目 & Scenedesmus acutus & 14 & 4 & + & 1 & \multirow{3}{*}{$2 \sim 9, \quad 7 \sim 35$} \\
\hline 17 & & & & Scenedesmus acutusf. alteraus & 5 & 2 & 1 & & \\
\hline 18 & & & & Scenedesmus arcuatus & 1 & $>$ & 1 & & \\
\hline 19 & & & クロ听ハキナ目 & Tetrachlorella spp. & & 2 & 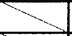 & & \\
\hline 20 & & & ヨツメモ目 & Gloeocystis sp. & 1 & 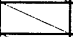 & W & $\infty$ & $4 \sim 13$ \\
\hline 21 & & & & Sphaerocystis sp. & 1 & $\infty$ & $\infty$ & C & $6 \sim 22$ \\
\hline 22 & & & 杖ミド咱 & Spirogyra sp. & & & $\infty$ & 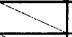 & $50 \sim 80, \quad 70 \sim 200$ \\
\hline 23 & & アオサ藻網 & 比ミ゙ト”咱 & Ulothrix zonata & 1 & $\infty$ & $\infty$ & $>$ & $20 \sim 45, \quad 15 \sim 30$ \\
\hline
\end{tabular}

（表中の数值は細胞数に基づく百分率 (単位\%). 表中の空欄は種の存在が確認されたものの, 細胞数が $0.5 \%$ 以下で あった種であり，斜線部は存在が確認されなかった種を表す. (*1) Homoeothrix spp.は系状体を1と計数している. (*2) Homoeothrix spp.については, 文献22)より属内の 4 つの種の基部および系状体の全長の範囲を示しており，他の種に関 しては, 文献 23)より, 球形のものに関してはその直径を, その他のものに関しては細胞直径と細胞長さ（珪藻綱羽状 目については殼長と殼幅)を記している.)

に基づく百分率より算出されたものである．全て の水路において，実験開始 5 日後と比較すると 34 日 後の方が系状体の藻類の割合が増加しており, Hoagland et al. ${ }^{2)}$ が指摘するような典型的な藻類種の 遷移が生じていることが分かる．水路間の違いに

ついては, 水路 3，4では実験開始より 34 日後には 付着藻類の細胞数に関して, $80 \%$ 以上が系状体の 藻類で占められており, 流速や底面付近の乱れが 大きい水路ほど, 系状体藻類の優占率が高くなる ことが分かる. 


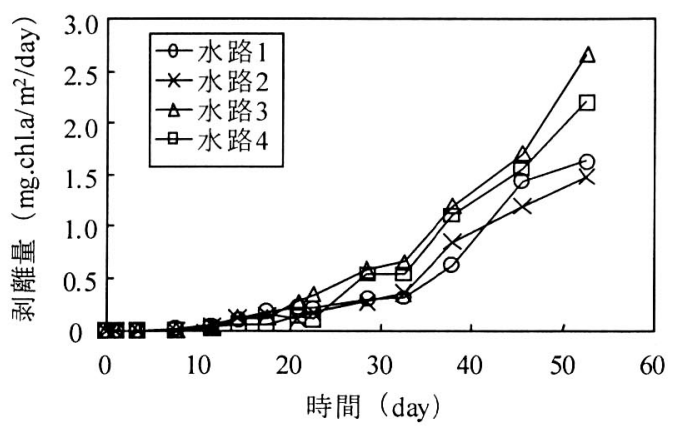

図-12 藻類剥離量の時系列変化 (Casel)

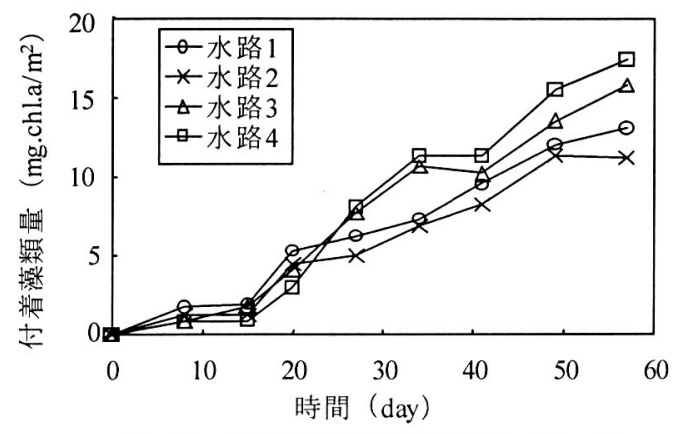

図-14 藻類現存量の時系列変化 (Case2)

\section{c) 藻類剥離量}

図-12 に付着藻類の一日当たりの剥離量の時系 列変化を示寸. 藻類量が増加する実験開始後 20 日 〜30日頃から剥離量が増加している. 水路間の違 いに関しては, 水路 1,2 と比較して水路 3，4のほ うが大きな值を示しているが，現存量で見られた ほどの大きな違いは無い.

付着藻類の現存量に対する剥離量の割合を検討 するため, 一日当たりの剥離量をその時点での現 存量で除すことにより剥離率を算出した。図-13に 剥離率の時系列変化を示す，全体的な傾向として， 剥離率は実験の進行に伴って増加しており，実験 開始初期に河床面に付着した藻類が，寿命や生理 活性の低下によって付着力が低下し剥離している ものと思われる．水路閒の違いについては，流速が 大きく河床面のせん断応力が大きくなる水路 3,4 より, 水路 1,2 の剥離率の方が大きな值を示して いる．剥離率の小さくなる水路 3，4 では系状体の 藻類が優占的に繁茂しており，このような種構成 の違いが水路間の剥離率の違いを引き起こしてい ることが分かる．以上のことより，付着藻類の剥離 は流体せん断力よりも藻類の生理的活動や藻類種 に依存していることが分かる.

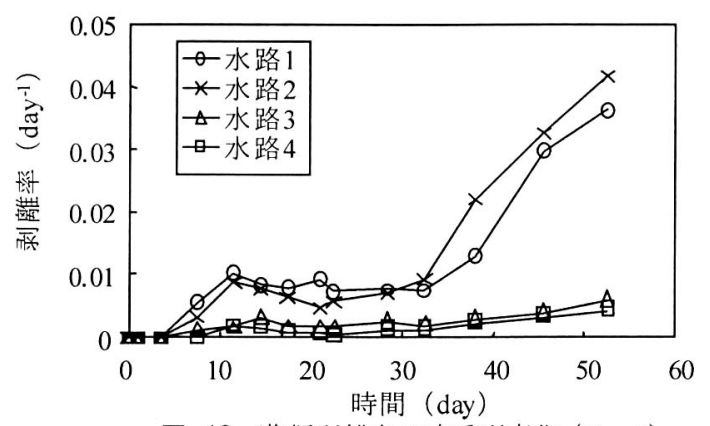

図-13 藻類剥離率の時系列変化 (Casel)

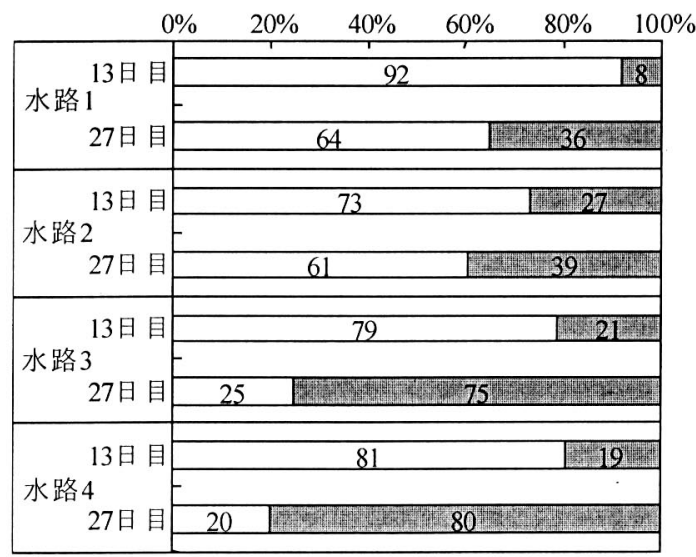

口単細胞・群体圆系状体

図-15 単細胞・群体型藻類と采状体藻類の割合（Case2）

\section{（3）実験結果 2 -半球状突起を有する水路床一}

\section{a) 藻類現存量およびー次生産力}

図-14にCase2 における付着藻類現存量の時系列 変化を示す．全ての水路において，実験開始から現 存量が除々に増加し，実験開始より 50〜 60日後に 至っても緩やかな増加が続いている．実験開始か ら50〜60日後における各水路の藻類量については Case1 ほど顕著では無いものの，水路床勾配の大き な水路ほど大きくなる傾向が見られ，流速や水路 床近傍の乱れの大きな水路ほど藻類一次生産力が 高いことが再確認される.

\section{b) 藻類の種組成}

表 -10 (a)，(b) に実験開始より 13 日後と 27 日後に おける付着藻類種の分析結果を示す（表 -9 と同様 に細胞数に基づく百分率)。13 日後の時点では水路 1,2 で藍藻綱と緑藻綱, 水路 3,4 で藍藻綱を中心 とた群落が生育しているが，27 日後には Casel と同 様に全ての水路において藍藻綱を中心とした群落 へと遷移している.

図-15に各水路の付着藻類を系状体と単細胞・群 体に分類し，その割合を細胞数に基づき算出した 結果を示寸，全ての水路において，実験開始より13 
表-10 半球状突起を有する水路に生育する藻類の種構成

(a) 実験開始より13日後

\begin{tabular}{|c|c|c|c|c|c|c|c|c|c|}
\hline No. & 植物門 & 網 & 目 & 種名 & 水路 1 & 水路 2 & 水路3 & 水路 4 & $\begin{array}{l}\text { 細胞の大きさ } \\
(\mu \mathrm{m})\left({ }^{*} 2\right) \\
\end{array}$ \\
\hline 1 & \multirow[t]{3}{*}{ 藍色門 } & \multirow[t]{3}{*}{ 藍藻網 } & \multirow[t]{2}{*}{ クロオコックス目 } & Chroococcusu spp. & 1 & 12 & 1 & 23 & $8 \sim 32$ \\
\hline 2 & & & & Gloeocapsa spp. & 51 & 2 & 53 & 34 & $8 \sim 90$ \\
\hline 3 & & & 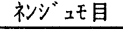 & Homoeothrix spp. $\left({ }^{*} 1\right)$ & 8 & 27. & 23 & 8 & $2.5 \sim 15,50 \sim 600$ \\
\hline 4 & \multirow[t]{13}{*}{ 不等毛門 } & \multirow[t]{13}{*}{ 珪藻網 } & \multirow[t]{13}{*}{ 羽状目 } & Fragilaria $\mathrm{sp}$. & $\infty$ & & $\infty$ & 2 & $40 \sim 170, \quad 2 \sim 4$ \\
\hline 5 & & & & Synedra ulna & $\infty$ & & $\infty$ & $-\infty$ & $50 \sim 350, \quad 5 \sim 9$ \\
\hline 6 & & & & Cocconeis placentula & $\infty$ & & & $\infty$ & $20 \sim 60, \quad 10 \sim 40$ \\
\hline 7 & & & & Achnanthes minutissima & 5 & 3 & 1 & 1 & $5 \sim 25, \quad 3 \sim 4$ \\
\hline 8 & & & & Navicula radiosa & 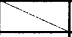 & 1 & $\infty$ & 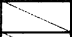 & $5 \sim 20, \quad 3 \sim 10$ \\
\hline 9 & & & & Amphora sp. & & 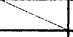 & $\infty$ & $\infty$ & $10 \sim 50, \quad 7 \sim 18$ \\
\hline 10 & & & & Cymbella leptoceros & $\infty$ & 1 & 2 & +2 & $15 \sim 60, \quad 7 \sim 13$ \\
\hline 11 & & & & Cymbella ventricosa & $\infty$ & & $\infty$ & $\infty$ & $15 \sim 60, \quad 7 \sim 13$ \\
\hline 12 & & & & Gomphonema paryulum & 4 & 5 & 3 & 2 & $10 \sim 40, \quad 5 \sim 8$ \\
\hline 13 & & & & Gomphonema olivaceum & 4 & & & & \\
\hline 14 & & & & Nitzschia palea & 5 & 6 & 6 & 7 & $20 \sim 65, \quad 3 \sim 5$ \\
\hline 15 & & & & Nitzschia scalpeliformis & & $x_{1}$ & & 2 & $40 \sim 100, \quad 6.5 \sim 9$ \\
\hline 16 & & & & Nitzschia sp. & & & 1 & & \\
\hline 17 & \multirow[t]{2}{*}{ 緑藻門 } & \multirow[t]{2}{*}{ 緑藻綱 } & \multirow[t]{2}{*}{ クロロבックム目 } & Oocystis spp. & 24 & 42 & 11 & 22 & $9 \sim 13,9 \sim 19$ \\
\hline 18 & & & & Scenedesmus spp. & 2 & 3 & 1 & 2 & $2 \sim 9, \quad 7 \sim 35$ \\
\hline
\end{tabular}

(b) 実験開始より 27 日後

\begin{tabular}{|c|c|c|c|c|c|c|c|c|c|}
\hline No. & 植物門 & 網 & 目 & 種名 & 水路 1 & 水路 2 & 水路 3 & 水路 4 & $\begin{array}{c}\text { 細胞の大きさ } \\
(\mu \mathrm{m})\left({ }^{*} 2\right)\end{array}$ \\
\hline 1 & \multirow[t]{4}{*}{ 藍色門 } & \multirow[t]{4}{*}{ 藍藻網 } & \multirow[t]{2}{*}{ クロオコックス目 } & Chroococcusu spp. & & 3 & & 1 & $8 \sim 32$ \\
\hline 2 & & & & Gloeocapsa spp. & 30 & 39 & 19 & 14 & $8 \sim 90$ \\
\hline 3 & & & \multirow[t]{2}{*}{ 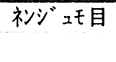 } & Homoeothrix spp. $\left({ }^{*} 1\right)$ & 36 & 39 & 75 & 80 & $2.5 \sim 15, \quad 50 \sim 600$ \\
\hline 4 & & & & Oscillatoria spp. & 2 & & $\$$ & & $2 \sim 3, \quad 2 \sim 8$ \\
\hline 5 & \multirow[t]{5}{*}{ 不等毛門 } & \multirow[t]{5}{*}{ 珪藻網 } & & Fragilaria sp. & & & $\infty$ & $\infty$ & $40 \sim 170, \quad 2 \sim 4$ \\
\hline 6 & & & & Achnanthes minutissima & 4 & 6 & 1 & 1 & $5 \sim 25, \quad 3 \sim 4$ \\
\hline 7 & & & & Amphora sp. & $\infty$ & & & $\infty$ & $10 \sim 50, \quad 7 \sim 18$ \\
\hline 8 & & & & Gomphonema parvulum & 2 & 1 & & & $10 \sim 40, \quad 5 \sim 8$ \\
\hline 9 & & & & Nitzschia palea & 1 & 2 & 1 & & $20 \sim 65, \quad 3 \sim 5$ \\
\hline 10 & \multirow[t]{3}{*}{ 緑藻門 } & \multirow[t]{3}{*}{ 緑藻網 } & \multirow[t]{2}{*}{ クロロコックム目 } & Oocystis spp. & 26 & 8 & 2 & 3 & $9 \sim 13,9 \sim 19$ \\
\hline 11 & & & & Scenedesmus spp. & 2 & 1 & & 1 & $2 \sim 9, \quad 7 \sim 35$ \\
\hline 12 & & & 杖ド口目 & Closterium spp. & & & $\alpha$ & & $30 \sim 50, \quad 250 \sim 800$ \\
\hline
\end{tabular}

(表中の数值は細胞数に基づく百分率 (単位\%). 表中の空欄は種の存在が確認されたものの, 細胞数が $0.5 \%$ 以下で あった種であり, 斜線部は存在が確認されなかった種を表す. $\left({ }^{*} 1\right)$ Homoeothrix spp. は系状体を 1 と計数している.

(*2)Homoeothrix spp. については, 文献 22)より属内の 4 つの種の基部および糸状体の全長の範囲を示しており，他の種 に関しては, 文献 23)より, 球形のものに関してはその直径を, その他のものに関しては細胞直径と細胞長さ（珪藻網 羽状目については殼長と殼幅) を記している.)

日後の時点では単細胞・群体の藻類細胞数が $70 \%$ 以 上を占めているが, その後系状体藻類の優占率が 増加していることが示されている．各水路間の違 いについてみると，水路 $1 ， 2 ， 3 ， 4$ の順で系状体 藻類の優占率が増加しているが，その違いはCase 1 ほど大きくはなく，このことが藻類現存量の水路 間の違いを小さくしているものと推察される.

\section{c) 藻類剥離量}

図 -16 に藻類剥離量, 図 -17 に剥離率の時系列変 化を示す. Case 1 と同様に, 藻類の増殖に伴って剥 離量が増加している．水路間の剥離率の違いに関 しては, Case1で見られたような明確な違いは観察 されなかった。このことは各水路間の藻類種の構 成が Case1 ほど大きく異ならなかったので, 種組成 の違いによる剥離率の相違が小さかったと思われ る.

\section{d) 半球周辺の藻類の付着分布}

写真 -1 (a)，(b) に水路 4 における実験開始より 27 日後および 41 日後における半球状突起への藻類付 着状況の写真を示す，写真中の黒ずんだ部分は，藻 類が大量に付着していることを示している．藻類 の付着は半球の流れに対して下流側の面で集中的 に生じており，上流側の面と下流側の面の間には, 付着量の違いによる境界が確認される，表一11に実 験開始より 27 日後および 41 日後の半球の上流側の 面，頂部，下流側の面それぞれに付着していた藻類 量を示す. 27 日後, 41 日後のいずれにおいても，半 球の上流側の面と比較して頂部，下流側の面の付 着藻類量が多い. 半球近傍の流れは上流面と下流 面の境界付近で剥離し，その下流側では乱れの大 きい剥離域が形成されることが知られている25). 一方, 剥離域の上流側では, 剥離域内と比較して, 


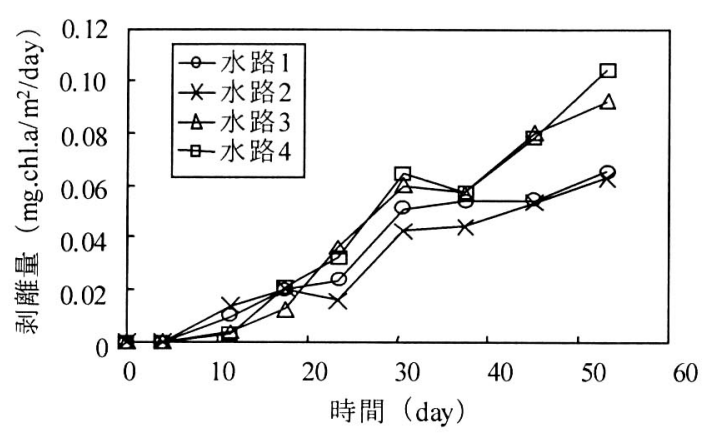

図-16 藻類剥離量の時系列変化 (Case2)

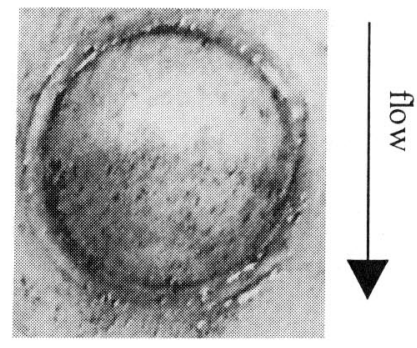

（a）実験開始後 27 日（水路 4）

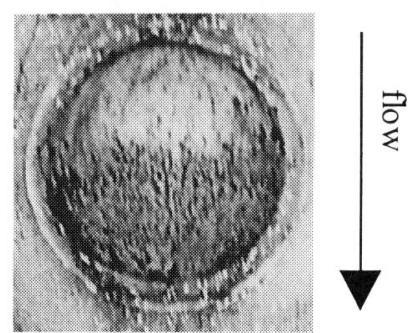

(b) 実験開始後 41 日（水路 4)

写真-1 半球状突起への藻類付着状況

平均流速が大きく，乱れが小さな流れとなる。この ことを考虑すると, 付着藻類量は流速の大きさよ りも付着面近傍の乱れの大きさの影響を強く受け， 乱れが大きいほど藻類一次生産力が高くなること が推論される。

\section{4. 結論}

本研究では, 現地観測および室内実験により水 理特性が付着藻類の一次生産特性に与える影響に 関する検討を行った．本研究の範囲内において以 下の知見が得られた.

1)水温, 河床面での日射量, 栄養塩濃度がほぼ等し い実河川中の瀬と淵においては，瀬の方が淵より も高い一次生産力を示す.

2) 観測地における日中の溶存酸素濃度の増加は,

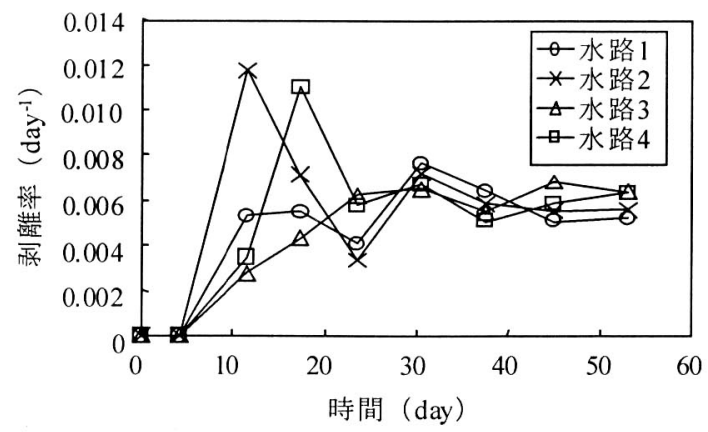

図-17 藻類剥離率の時采列変化 (Case2)

表-11 半球周りの藻類付着量分布

\begin{tabular}{|c|c|c|c|c|}
\hline 計測日 & 水路番号 & 上流側の面 & 頂部の面 & 下流側の面 \\
\hline \multirow{4}{*}{$\begin{array}{l}\text { 実験開始 } \\
\text { 後27日目 }\end{array}$} & 水路1 & 4.0 & 12.0 & 9.5 \\
\hline & 水路2 & 5.1 & 8.9 & 7.8 \\
\hline & 水路3 & 6.3 & 11.6 & 8.1 \\
\hline & 水路4 & 11.2 & 14.1 & 12.1 \\
\hline \multirow{4}{*}{$\begin{array}{l}\text { 実験開始 } \\
\text { 後 } 41 \text { 日目 }\end{array}$} & 水路1 & 5.4 & 15.3 & 14.3 \\
\hline & 水路 2 & 4.9 & 15.3 & 12.5 \\
\hline & 水路3 & 11.8 & 19.4 & 19.9 \\
\hline & 水路4 & 15.1 & 25.6 & 25.5 \\
\hline
\end{tabular}

(単位 : mg.chl.a/m²)

藻類の一次生産活動によって引き起こされる.

3) 付着藻類の一次生産力は, 底面近傍の乱れが大 きい場合ほど大きな值を示す。

4) 付着藻類の剥離は, 流れのせん断力よりも藻類 の種組成や生理的特性の影響を受ける.

5) 流速や底面近傍の乱れが大きな水路では, 系状 体の藻類の細胞数に基づく優占率が高くなる.

今後, 藻類一次生産特性に関してさらなる定量 的評価を行っていくためには, 藻類種毎の生理特 性（一次生産速度, 付着強度, 代謝速度) を明らか にすることが必要であり, 今後の重要な課題であ る.

謝辞：本研究の実行にあたり，東京都交通局多摩川 第 3 発電所から御岳橋流量データを提供していた だいた。水質分析時には東京工業大学総合理工学 研究科石川忠晴教授および石川研学生諸氏の援助 を受けた。藻類種の分析については東京大学緑地 研究所加藤一弘助教授の援助を受けた。 また，本研 究は日本学術振興会科学研究費基盤研究 $(A)$ (2)（課 題番号：11305035, 研究代表者：池田駿介）および 同科学技術研究費奨励研究 (A)（研究代表者: 戸田 祐嗣, 課題番号：11750451）の補助を受けた。記し て謝意を表する。 


\section{参考文献}

1) 例えば, 水野信彦, 御勢久右衛門: 河川の生態学, 築 地書館, 1972.

2) Hoagland, K. D., Roemer, S. E., and Rosowski, J. R.: Colonization and community structure of two periphyton assemblages, with emphasis on the Diatoms (Bacillariophycese), American Journal of Botany, No. 69, pp.188-213, 1982.

3) Lobo, E. A., Katoh, K. and Aruga, Y.: Response of epilithic diatom assemblages to water pollution in rivers in the Tokyo Metropolitan area, Japan, Freshwater Biology, No. 34, pp.191204, 1995.

4) Biggs, B. J. F., Goring, D. G. and Nikora, V. I.: Subsidy and stress responses of stream periphyton to gradients in water velocity as a function of community growth form, Journal of Phycology, No.34, pp.598-607, 1998.

5) 池田駿介, 戸田祐嗣, 佐野貴之 : 現地観測に基づく瀬 の水理と生物一次生産に関する研究, 土木学会論文集, No.593, pp.93-103, 1998.

6) 有賀祐勝: 水界植物群落の物翼生産 I , 共立出版, 1973.

7) 池田駿介, 戸田祐嗣, 赤松良久 : 瀬と淵の水質および 生物一次生産に関する現地観測, 水工学論文集, 第 43 巻, pp.1037-1042, 1999.

8）赤松良久, 戸田祐嗣, 池田駿介 : 河床付着性藻類の増 殖と剥離に関する実験的研究，河川技術に関する論文 集, 第 6 巻, pp.119-118, 2000.

9) 戸田祐嗣, 赤松良久, 池田駿介 : 平坦河床上の藻類の 増殖と剥離に関する研究, 水工学論文集, 第 45 巻, pp.1111-1116, 2001.

10) Stevenson, R. J., Christopher, P. G., Kirschtel, D. B., King, C. C. and Tuchman, N. C.: Density dependent growth, ecological strategies, and effects of nutrients and shading on benthic diatom succession in streams, Journal of Phycology, No.27, pp.5969, 1991.

11) DeAngelis, D. L., Loreau, M., Neergaard, D., Mulholland, P.
J. and Marzolf, E. R.: Modelling nutrient-periphyton dynamics in streams: the importance of transient storage zones, Ecological Modelling, No.80, pp.149-160, 1995.

12) Momo, F. R.: A new model for periphyton growth in running water, Hydrobiologia, No.299, pp.215-218, 1995.

13) Saravia, L. A., Momo, F. R., and Lissin, L. D. B.: Modelling periphyton dynamics in running water, Ecological Modelling, No.114, pp.35-47, 1998.

14) 浅枝隆, ズン・ソンホン, 藤野毅 : 河床のペリファイ トンの遷移過程の解析, 河川技術に関する論文集, 第 6 巻, pp.119-124, 2000.

15) 厚生省生活衛生局水道環境部監修: 上水試験方法, 日 本水道協会, 1993.

16)半谷高久, 小倉紀雄: 水質調查法, 丸善, 1995

17) 楠田哲也編著 : 自然の浄化機構の強化と制御（第 1 章)，技報堂出版，1994.

18) 日本化学会編: 陸水の化学 (II -10), 学会出版センター, 1992.

19)土木学会編: 水理公式集 (第1編11章), 土木学会, 1987.

20) 日本海洋学会編: 海洋環境調査法 (第6 章), 恒星社厚 生閣, 1987.

21) 西澤一俊, 千原光雄: 藻類研究法, 共立出版, 1979.

22) 廣瀬弘幸編 : 日本淡水藻図鑑, 内田老鶴圃新社, 1977.

23) 小島貞男, 須藤隆一, 千原光雄編: 環境微生物図鑑, 講 談社, 1995.

24) 大橋晶良, 原田秀樹, 桃井清至 : 平板上に形成される 脱窒処理生物膜の成長過程, 衛生工学研究論文集, No.27, pp.45-54, 1991.

25) 高橋迪夫 : 水路床上に存在する半球下流部の流れの構 造に関する実験的研究, 土木学会論文集, No.417, pp.73-82, 1990.

(2001. 5. 23 受付)

\title{
STUDY ON PRIMARY PRODUCTIVITY OF PERIPHYTON IN STREAMS IN RELATION TO HYDRAULIC CONDITIONS
}

\author{
Yuji TODA, Yoshihisa AKAMATSU and Syunsuke IKEDA
}

Field observations on the characteristics of primary production of periphyton were performed at riffles and pools in Tama-river, where many artificial gravels were settled on the bottom. The amount of periphyton growing on them was measured every week for 55 days. It was found that the periphyton growing on the gravels at riffles has larger photosynthetic activity than that at pools. The measurements on the growth of periphyton were conducted in 4 tandemly placed laboratory flumes, in which the environmental conditions except for the hydraulic conditions were controlled to be the same among the flumes in order to estimate the effects of hydraulic characteristics on the primary production of periphyton. The results of the experiments indicate that the primary production of periphyton takes large value for the case where the near-bottom turbulence is large. 